\title{
Canada's long road to a vaccine injury compensation program
}

Cite as: CMAJ 2021 February 22;193:E294-5. doi: 10.1503/cmaj.1095922

Posted on cmajnews.com on February 5, 2021

W

ork is underway on a new panCanadian no-fault vaccine injury compensation program, but it may be months before the scheme is operational.

Prime Minister Justin Trudeau announced the Vaccine Injury Support Program in December following a meeting with provincial premiers on the COVID-19 pandemic and other issues. The program will provide financial support to people who experience a serious permanent injury after receiving any vaccine approved by Health Canada.

"Serious side effects are incredibly rare," said Trudeau. "In the very unlikely event of an adverse reaction, though, we want to make sure Canadians have fair access to support."

Although the wording of a Health Canada news release suggested the program was imminently operational, it has not been set up yet. According to a spokesperson, the federal government is committed to working with the provinces and territories on its development, and negotiations are ongoing. The spokesperson told CMAJ the program will launch sometime in 2021.

A Canadian researcher who has been advocating for a national vaccine injury compensation program for more than a decade welcomed the announcement and said he is optimistic that it will come to fruition. "There are many, many details in how a program gets implemented, but I think once an announcement like this is made, and if vaccine manufacturers are expecting the program, it's going to be hard not to follow through," said Dr. Kumanan Wilson, a physician-scientist at the Ottawa Hospital.

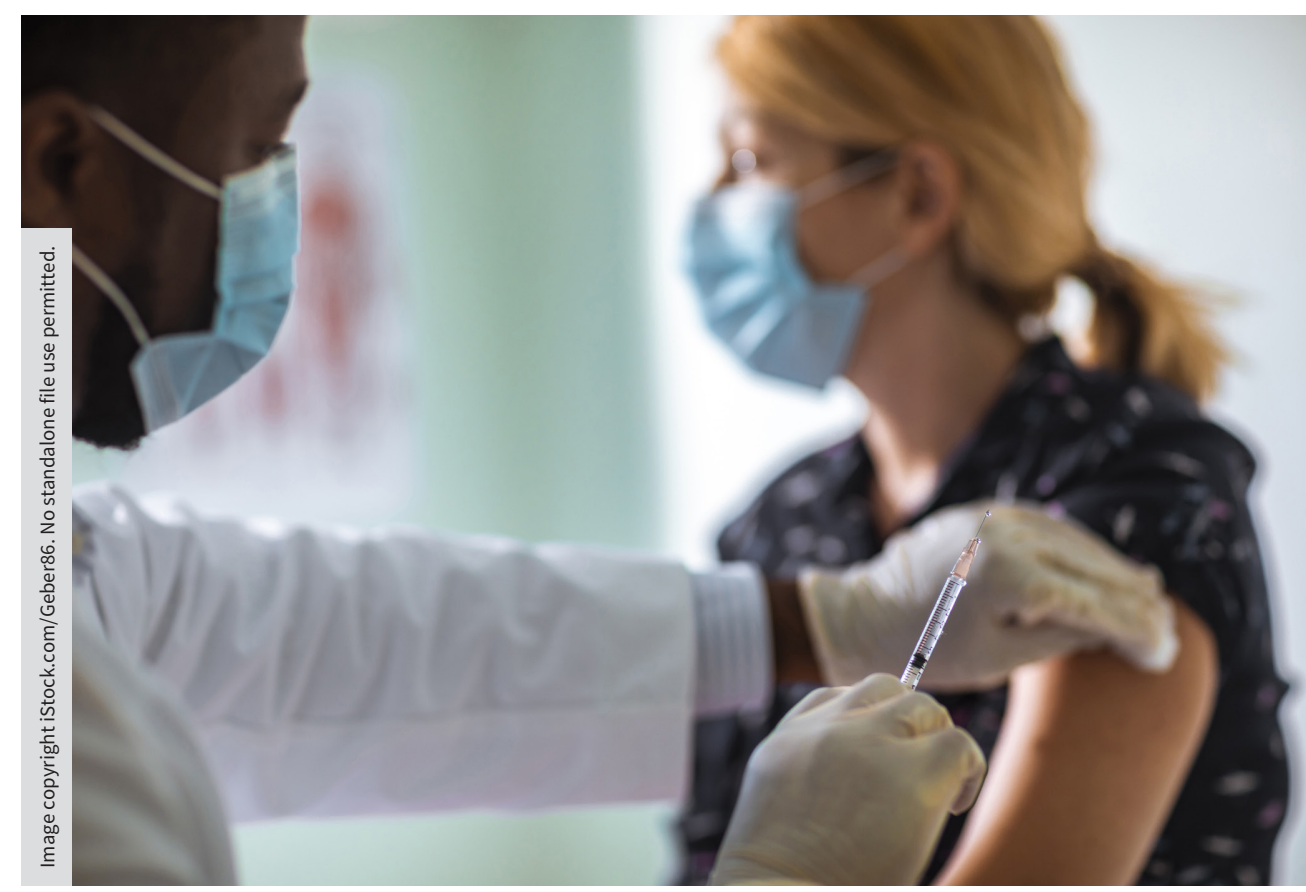

The federal government is still negotiating a promised vaccine injury compensation program with the provinces and territories.

However, the federal, provincial and territorial governments have failed to agree on a compensation program to date.

Canadian health experts have been calling for a national vaccine injury compensation program since at least the mid-1980s. Canada is seen as an outlier in this respect as 19 countries have national vaccine injury support programs, including all other $G 7$ nations, according to Wilson.

"It's a fundamental part of any immunization program to have vaccine injury compensation, for multiple reasons," he said. First, "it's the right thing to do for the public, particularly during COVID."

Such programs also support innovation and protect vaccine makers, Wilson said.
Prior to the United States introducing a vaccine injury compensation scheme in the 1980s, manufacturers were abandoning the business due to a flood of litigation over adverse events linked to a whole-cell pertussis vaccine.

Quebec has had a vaccine injury compensation program since 1985 , spurred by the 1979 case of a five-year-old girl who developed viral encephalitis shortly after receiving a measles vaccination. Attempts were made to develop a national program at that time, but federal and provincial deputy health ministers refused to fund it in the absence of accurate estimates of vaccine-related injuries.

In a recent review of existing vaccine injury compensation programs, Ėve Dubé 
and colleagues found that Quebec's program had processed 228 claims as of April 2018. Of those, 187 met the criteria for evaluation, and 43 were approved, with $\$ 5.49$ million paid in compensation.

For a more than 30-year-old program, those numbers represent relatively few claims, said Dubé, who is a medical anthropologist and researcher at Laval University and the Quebec National Institute of Public Health.

By comparison, the U.S. program has evaluated more than 19500 claims and approved 7807 since 1988 . According to Dubé, Quebec's program conducts a more detailed assessment of causality and the extent of a person's injury before it will consider a claim for compensation, which means the program reviews fewer claims but approves a higher percentage. The Quebec model will likely serve as the template for the promised panCanadian program.

Many advocates for vaccine injury compensation schemes have suggested that such programs could improve public trust in vaccines - a key factor in achieving the high uptake needed for herd immunity.

However, Dubé noted her review found no evidence to suggest that the programs have any impact on public opinion for better or worse. Having a vaccine injury compensation program is "good public health practice," she said.
"But it might not be the intervention to solve the vaccine hesitancy issue."

Terry Murray, Toronto, Ont.

Editor's note: Kumanan Wilson is the husband of CMAJ's communications specialist, who has no role in news decision-making or any part of this article.

Content licence: This is an Open Access article distributed in accordance with the terms of the Creative Commons Attribution (CC BY-NC-ND 4.0) licence, which permits use, distribution and reproduction in any medium, provided that the original publication is properly cited, the use is noncommercial (i.e., research or educational use), and no modifications or adaptations are made. See: https://creativecommons.org/ licenses/by-nc-nd/4.0/ 